\title{
Woman's Subordination in Politics in West Sumatera
}

\author{
Zulvia Trinova, Rezki Amelia, Gusmirawati, Rosdialena \\ State Islamic University Imam Bonjol Padang, West Sumatra, Indonesia
}

\begin{abstract}
Indonesia government has placed politically the chance for women to participate in political field because the women representation is still low if it is compared with men locally and nationally. Meanwhile, the involvement of women in politics becomes one of indicators to determine Gender Empowerment Measurement (GEM). West Sumatra which is well-known as Bundo Kanduang provides important position for women in making decision, either in custom, nagari, communal society. The aim of the study is to describe women participation in politics. It is also to identify some factors which influence the women representation in legislative level. Qualitative research was used in this study where the data taken from interview, documentation, and observation. 24 candidate of legislative in 2014 were involved in this study. The finding of the study showed that there was only $7.38 \%$ women got the position in legislative. The women participation is lower than 2009. The other finding described some factors that influenced the women involvement in parliament. It was caused by: (1) there is a stereotype of society that politics is for men only; (2) the process of selection in politic still subordinate women; (3) lack of publication support in parliament; (4) there is no organization, group and networking which not commit to support women in parliament; (5) there is no good support from family to involved in politics. It is suggested that the government should improve the women representation in legislative.
\end{abstract}

Keywords: women subordination, politics, parliament

\section{Introduction}

Women involved in politics can be seen in different contexts, such as through their participation as voters in elections, their involvement in the political arena as candidates, and as members of the bureaucracy, political offices, or parliaments. This research examines women's political participation and their election as members of local parliament in the Indonesian Province of West Sumatra. This participation of women in politics has been the subject of considerable research that has often associated it with the goals of equality and justice and the practice of democracy. Despite the establishment of candidate quotas and other measures to increase women's participation in politics, one finds that in many parts of the world women's involvement is, still considerably less than that of men; that is, less than one out of five members of parliament is a woman (Dahlerup, 2005; Stockemer, 2009).

Participation has generally not achieved the levels of participation by men (Inglehart \& Norris, 2003; Paxton, Hughes, \& Painter, 2010; Paxton, Kunovich, \& Hughes, 2007). A range of factors has been identified, including economic factors such as human and financial capital and the presence of female workers in the

Zulvia Trinova, S.Pd., M.A., Islamic Education Department, State Islamic University Imam Bonjol Padang. Rezki Amelia, S.Pd., M.A., M.Pd., Islamic Education Department, State Islamic University Imam Bonjol Padang. Gusmirawati, S.Pd., M.A., Islamic Education Department, State Islamic University Imam Bonjol Padang. Rosdialena, S.Sos.I, M.A., Da'wah of Science Department, State Islamic University Imam Bonjol Padang. 
public space, which may contribute to whether it is advantageous for women to engage in political activity in these developed countries. However, other factors, such as institutional structures including government rules, political parties and the nature of the electoral system, such as any quota system and proportional representation, may influence the strategies of political parties in supporting female candidates (Paxton, 1997; Rule \& Zimmerman, 1994). Also, there is an idea that women's representation has a strong correlation with political culture. For example, women who live in regions that value gender equality might have wider opportunities to represent their community in politics (Thames \& Williams, 2013). However, a number of barriers for women in entering politics have been widely observed and include gender stereotypes, career choices and preparation, family demands, gender discrimination and the conventions of the political system, including money or fund raising, party organisation and support, the advantage of incumbency and the way the electoral system works (Carli \& Eagly, 2001).

Women participate in politics than men. This study will complement previous research by considering the issues surrounding women's participation in politics in West Sumatra, Indonesia. West Sumatra is one of 33 provinces in Indonesia and is populated almost entirely by the matrilineal Minangkabau people. Matrilineal system govern the life and societal structure are based on matrilineality of Minangkabau kinship (Radjab, 1969). It is hypothesized that the matrilineal system in this region will give rise to forces that contribute to differential political engagement among men and women in a system where patriarchal heritage should not be in influencing their social behaviour.

\section{Political Participation}

There are many possibilities that can occur by regarding the understanding of the participation process and also with a number of platforms related to participation itself. According to Davis (1997) participation is defined as: "mental and emotional involment of a person in group goal situations which encourages him to contribute to the group goal and share responsibility in them". Dhesi (2000) also noted that: "participation in development means how community members can be assured of the opportunity of contributing to the creation of the communities goods and services".

Meanwhile, Budiardjo (2003) devides participation as (1) autonomous participation, and (2) mobilization participation. Cohen and Uphoff (1977) differentiate the participation into; (1) voluntary participation, (2) induced participation, (3) forced participation. Whereas according to Van Deth (2001), in the 1950s participation was used in political terms, which meant voting, party membership, voluntary association activities, process activities, etc. Then in the 1970s the notion of participation was associated with administrative processes (Cohen \& Uphoff, 1977). While the way to participate in two types of participation, namely: participation in joint activities in specific development projects, and participation as individuals outside of joint activities in development (Hadi, 2010; Mikkelsen, 2011; Purnamasari, 2008). Based on the systems and mechanisms of participation, Cohen and Uphoff (1977) distinguish participation into four types: (1) Participation in decision making, is community participation in decision-making processes and organizational policies. This kind of participation gives the opportunity to the community in expressing their opinions to assess a plan or program to be determined. Communities are also given the opportunity to assess a decision or policy in progress. Participation in organization decision making is commonly seen as a means of reducing the relative power of the executive elites, but also as a way toward a more general democratization of society (De Dreu \& West, 2001; Irvin \& Stansbury, 2004; Renn, Webler, Rakel, Dienel, \& Johnson, 1993; Witt, Andrews, 
\& Kacmar, 2000); (2) Participation in implementation, is the participation of the community in the operational activities of development based on the established program. In the development program, the form of community participation can be seen from the number of the active communty in participating such as labor, materials, money, direct or indirect participation; (3) Participation in benefits; (4) Participation in evolution, is the participation of the community in assessing and overseeing development activities and their results. This assessment is done directly, for example by participating in a committee or assessment team; indirectly, such as giving suggestions, criticism or protest. This sort of participation is a part of social control.

In developing countries, the issue of participation is a complicated issue. Participation becomes the benchmark of acceptance of the political system built by a country. The progress and development within a country is highly dependent on the involvement of its citizens regardless of sex, male or female. Understanding political participation is very broad. Considering that political participation itself is one of the important aspects of democracy. The underlying assumption of democracy (and participation) of people who know the best about what is good for itself is the person himself (Hamad, 2008; Shafiyyah, 2003; Simamora, 2011; Winarno, 2007). Because the political decisions made and implemented by the government are concerning and affecting the lives of its citizens, the citizens are entitled to participate in determining the political decisions.

The equal participation between man and woman in public life is one of the fundamental principles mandated in the Convention on the Elimination of All Forms of Discrimination Against Woman (CEDAW) adopted by the General Assembly of the United Nations in the year 1979 and passed in 1981. Of 190 countries, only seven countries where woman become president or prime minister. The presence of woman as part of the existing cabinet in this world or being a mayor, did not reach the number of 7 and 8 in percentage. Now, more than 20 years since the signing of the convention shows that woman all over the world are still marginalized and underrepresented in the political world especially for their involvemant in public decisions.

Based on these data, it can be seen that the gender gap in public life and politics is a global challenge that continues to be faced by the world community in the 21 st century. Despite various conventions and international commitments, the average number of woman in parliament in this world only 18.4 percent. Indonesia was in the 80th of 156 countries in the Gender Development Index (GDI) in 2007. In 2009, this number fell to the order of 90, meaning that woman in Indonesia still do not enjoy the same rights and standards as the man. GDI measures human development, but it takes into account gender differences. The GDI components are similar to those used in the Human Development Index (HDI), but it is adjusted to see differences in achievements between woman and man; three indicators were used including life expectancy, measured by life expectancy at birth; educational achievement, measured by a combination of reading ability among adults and the average number of years attending school; the standard of living, measured by per capita expenditure. That woman are still left in these areas indicates that there is still a way for woman to be truly equal in Indonesian society.

In recent times, the gender equality issues have become prominent in the development platform, not only in Indonesia but also internationally. We certainly understand that woman are socially marginalized. Partriarchic culture that is not friendly to woman. There is a socio-cultural construction that places woman as if they should only take care of domestic matters. There is no right to reach other public areas. This fact shows that the belief is still firmly planted in society. The issue of woman's representation becomes important when in daily life it can be seen that woman are not proportionally involved in public life. It is very sad when 
considering from the composition of the population between man and woman are almost balanced while the representation of woman in the legislative is still very limited in number, which is still a common thought.

As McDonald (2000) argues, realizing gender equality is one of the efforts to achieve democratization, because with gender equality, it will open up the opportunities and the accessibilty for all people to participate in the process of democratization itself. The efforts to realize gender equality have so far been done by quite a number of parties. But the reality that occurs in society is still a lot of gender injustice practices in various aspects of life that mostly experienced by woman. That fact inhibits the ideals of democratization itself because there is still discrimination.

So far, there is an assumption that the world of politics is synonymous with the world of man. This assumption arises from an incomplete "image" of political life; namely that politics is dirty, hard, full of intrigue, etc. which is identical with the characteristics of man as a result, the number of woman engaged in a small political world, including in countries where democracy and equality of rights are quite high. In addition, such an impression arises because historically, especially in the early stages of human development, man are always synonymous with "agencies" or work activities outside the house, while woman are in charge of preparing family needs in the house such as cooking, parenting, and serving husband.

So regarding from the existing reality of woman's representation in politics, it is still far from expectations. Wulan (2008) reveals that "woman have been in actitive and present, at time in large numbers than man in our public demonstrations. But when it comes to political appointments, they are pushed aside". In other words, woman as a relatively more than man have always been involved in political endeavors such as "seizing the independence", involving the large-scale demonstrations in overthrowing the ruling regime, but often marginalized when the political agenda was over. This reality is proven from the fact that woman in almost all parts of the world are not represented proportionately in politics. Woman occupy only 14.3 percent of the total seats of parliament. Scandinavian countries such as Sweden, Norway, have the highest female representation rate, which is 40 percent, while the lowest number is Arab countries about 4.6 percent (Lovenduski \& Karam, 2002).

Therefore, the efforts to improve woman's political representation in Indonesia is an urgent need. Increasing woman's political representation is tantamount to increasing their effectiveness in influencing political decisions that can guarantee the economic rights of woman and the wider community, and also allocating the resources needed to improve the quality of human life. Beside that, the need to increase woman's representation is also based on the fact that woman's representation in legislative institutions in Indonesia both at the national and local levels is still very low.

\section{Method}

This study takes a qualitative approach which can be defined as the collection of data through written text, spoken words and observable behaviours and the subsequent description and analysis of those data (Patton, 1990; Taylor, Suckling, \& Rachlinski, 2005; Taylor, Bogdan, \& DeVault, 2015). In qualitative research, there are typical data collection methods that include interviews, conversations, observations, taking pictures, recordings, videos, field notes (Bloomberg \& Volpe, 2008; Lincoln \& Denzin, 2003). These activities may be combined with data from other sources that may include a range of documents and other secondary sources.

To identify female politicians, women who had served as legislators, information was obtained from the Electoral Commission of West Sumatra on the number of female legislators in the 20 local parliaments in the 
province. The areas in which they lived and which they represented were considered, and potential respondents were chosen by random selection from among eligible individuals based on the selected criteria. Once potential respondents were identified, these female legislators were contacted individually by phone to ask if they were willing to be interviewed. Each one was given a few days to consider her participation in the study and then was contacted again by the researcher. The researcher then went to see those who agreed to take part so they could read and sign the consent forms and other documentation relating to the research.

The women who participated in this study included those with incumbent status who were elected for the first-time during the periods 2004-2009 and 2009-2014. The reason for focusing on women in parliament in these two time periods was because these electoral periods occurred during the Reform Era since the establishment of regional autonomy at the local government level in the Indonesian system.

Data from the Electoral Commission at the provincial level shows that 5 (9\%) of 55 members of parliament (MPs) for the period 2004-2009 were women as were 7 (12\%) of 55 MPs for the period 2009-2014. There were 39 (7\%) women among 551 MPs in regional parliaments in the 19 municipalities and regencies within the province of West Sumatra for the period 2004-2009, and 44 (8\%) women among 555 MPs in the 19 regional parliaments in West Sumatra for the period 2009-2014. For these two periods in the 19 regional parliaments, 116 MPs (both men and women) were incumbents and 16 (7\%) of these incumbents were women. Thus, the total number of women legislators that were available to be interviewed from local parliaments at the municipality and regency levels was 67 with an additional 12 at the provincial level. Based on availability and desire to participate, the respondents for this study consisted of three members of local parliaments who had been MPs for two terms or more, one who was elected in the 2004-2009 period and lost her seat in 2009-2014, and one who was elected for the first time in 2004-2009. These respondents were expected to provide a variety of insights in the current and past political process and to reflect on the unique aspects of their experience as it related to the matrilineal context of which they were a part.

In the present study, the researcher is a woman and a member of the Minangkabau society of West Sumatra. While this provided certain benefits, such as the ability to use the local language as well as Indonesian in conducting interviews and an insider's understanding of social issues and norms, it also meant that the researcher may have had certain fixed ideas about the culture and its values as well as the ways in which women politicians are perceived by the public.

\section{Findings}

\section{Woman's Representation on Politics in West Sumatra}

Woman has an important role in the development of a nation. But nowadays, woman has not had a better chance in many areas of national and state life, including in politics and government. Woman is still considered to have less ability to play more role in making better policies in governance. Prior to 2009 General Election, there was an important policy related to the issue of woman's quota in the Indonesian political scene. One of the important policies was Law Number 10 Year 2008 regarding General Election. The Election Law is a core policy on the issue of woman's political representation in which affirmed the quota of woman in parliament. Following the release of the policy, woman was given the opportunity to play more in the political arena.

In Law Number 10 Year 2008 regarding to General Election, the members of the house of representative, the region Representatives Council, and the Region of the House of Representatives, act 53 mandates that political parties contain at least $30 \%$ of woman in their legislative candidate list. This article is reinforced by act 
55 verse (2) stating that in each of the three candidate names, there must be at least one female candidate. The woman's quota policy of at least $30 \%$ in the list of legislative candidates is also reinforced by government policy through Law No. 2 of 2008 on Political Parties. Woman's representation in politics, especially in the house of representatives (DPR / DPRD), is not without fundamantal reasons.

Based on 2004 election results, the representation of woman in legislative institutions in West Sumatra is still below the national average ( 9.2 percent), which was 8.03 percent, and even seen from districts, there are still five areas that do not have female legislators yet. It can clearly be seen in Table 1.

Table 1

The Members of the House of Representatives in Regency/City in West Sumatra (Election Results 2009-2014)

\begin{tabular}{|c|c|c|c|c|c|c|}
\hline \multirow{2}{*}{ No } & \multirow{2}{*}{ Regency/City } & \multirow{2}{*}{ Number } & \multicolumn{4}{|c|}{ Elected } \\
\hline & & & Male & $\%$ & Female & $\%$ \\
\hline 1. & West sumatera province & 55 & 50 & 90.91 & 5 & 9.09 \\
\hline 2. & Agam regency & 40 & 36 & 90 & 4 & 10 \\
\hline 3. & Pasaman regency & 30 & 28 & 93.33 & 2 & 6.67 \\
\hline 4. & Solok regency & 35 & 33 & 94.29 & 2 & 5.71 \\
\hline 5. & Pesisir Selatan regency & 40 & 39 & 97.50 & 1 & 2.50 \\
\hline 6. & 50 Kota regency & 35 & 31 & 88.57 & 4 & 11.43 \\
\hline 7. & Tanah Datar regency & 35 & 32 & 91.66 & 3 & 8.34 \\
\hline 8. & Padang Pariaman regency & 35 & 33 & 94.29 & 2 & 5.71 \\
\hline 9. & Sawahlunto Sijunjung regency & 25 & 25 & 100 & 0 & 0 \\
\hline 10. & Solok Selatan regency & 25 & 22 & 88 & 3 & 12 \\
\hline 11. & Pasaman Barat regency & 35 & 35 & 100 & 0 & 0 \\
\hline 12. & Dharmas Raya regency & 25 & 23 & 92 & 2 & 8 \\
\hline 13. & Mantawai regency & 20 & 20 & 100 & 0 & 0 \\
\hline 14. & Padang city & 45 & 39 & 86.67 & 6 & 13.33 \\
\hline 15. & Solok city & 20 & 20 & 100 & 0 & 0 \\
\hline 16. & Sawahlunto city & 20 & 19 & 95 & 1 & 5 \\
\hline 17. & Bukittinggi city & 20 & 15 & 75 & 5 & 25 \\
\hline 18. & Padang Panjang city & 20 & 19 & 95 & 1 & 5 \\
\hline 19. & Payakumbuh city & 25 & 21 & 84 & 4 & 16 \\
\hline 20. & Pariaman city & 20 & 20 & 100 & 0 & 0 \\
\hline Total & & 605 & 560 & 91.97 & 45 & 8.0163 \\
\hline
\end{tabular}

Note. Source: General Election Commitee (KPU) West Sumatra, 2014.

West Sumatra is one of the provinces that also participated in the 2014 election. Constitutionally, the rights of all Indonesian woman are no exception to whoever she is, from whatever background she entitled can register herself as a candidate (Ismanto, 2004). The woman in West sumatera deserved becoming the candidate of legislative carried by 15 political parties who passed the election verification and selection to follow the 2014 elections. For the Legislative Election of Woman in the Province of West Sumatera in the 2014 Election, only 7.38 percent of the woman sat in the house of representatives. This fact was still far from the 30 percent quota of woman representation in the Legislature. The results of the 2014 election can be seen from the Table 2.

From Table 2, it can be seen how inequality of the proportion of decision makers at the district/city level was seen real. Although for some areas, the percentage of woman involving in politics was relatively good, many other areas were still relatively low. Even there were still 5 regencies/cities that did not have female legislative members yet. This condition would greatly affect the various policies and decisions that were 
generated. The dominance of man who tend to be patriarchal and gender bias will always ignore woman's issues such as reproductive health, sexual violence, maternal and child health, etc. Whereas as described in the previous section, the proportion of woman's representation to the legislatuive will ensure the rights and interests of woman adequately.

Table 2

Data of Legislative Candidates of West Sumatra in the 2014-2019 Election

\begin{tabular}{|c|c|c|c|c|c|c|c|c|c|c|c|c|c|}
\hline \multirow{2}{*}{ No } & \multirow{2}{*}{ Political party } & \multicolumn{2}{|c|}{ Election area 1} & \multicolumn{2}{|c|}{ Election area 2} & \multicolumn{2}{|c|}{ Election area 3} & \multicolumn{2}{|c|}{ Election area 4} & \multicolumn{2}{|c|}{ Election area 5} & \multicolumn{2}{|c|}{ Total } \\
\hline & & $\mathrm{M}$ & $\mathrm{F}$ & $\mathrm{M}$ & $\mathrm{F}$ & $\mathrm{M}$ & $\mathrm{F}$ & $\mathrm{M}$ & $\mathrm{F}$ & $\mathrm{M}$ & $\mathrm{F}$ & M & $\mathrm{F}$ \\
\hline 1 & Nasdem & 6 & 3 & 6 & 3 & 7 & 3 & 5 & 3 & 6 & 3 & 30 & 15 \\
\hline 2 & PKB & 6 & 3 & 6 & 3 & 7 & 3 & 5 & 3 & 6 & 3 & 30 & 15 \\
\hline 3 & PKS & 6 & 3 & 6 & 3 & 7 & 3 & 5 & 3 & 6 & 3 & 30 & 15 \\
\hline 4 & PDIP & 6 & 3 & 5 & 3 & 6 & 4 & 5 & 3 & 6 & 3 & 28 & 16 \\
\hline 5 & Golkar & 6 & 3 & 6 & 3 & 7 & 3 & 5 & 3 & 5 & 3 & 29 & 15 \\
\hline 6 & Gerindra & 6 & 3 & 6 & 3 & 7 & 3 & 5 & 3 & 6 & 3 & 30 & 15 \\
\hline 7 & Demokrat & 6 & 3 & 6 & 3 & 7 & 3 & 5 & 3 & 5 & 4 & 29 & 16 \\
\hline 8 & PAN & 6 & 3 & 6 & 3 & 7 & 3 & 5 & 3 & 6 & 3 & 30 & 15 \\
\hline 9 & PPP & 6 & 3 & 6 & 3 & 7 & 3 & 5 & 3 & 5 & 3 & 29 & 15 \\
\hline 10 & Hanura & 6 & 3 & 6 & 3 & 7 & 3 & 5 & 3 & 6 & 3 & 30 & 15 \\
\hline 11 & PBB & 6 & 3 & 6 & 3 & 6 & 4 & 5 & 3 & 6 & 3 & 29 & 16 \\
\hline 12 & PKPI & 6 & 3 & 0 & 0 & 7 & 3 & 5 & 3 & 6 & 3 & 24 & 12 \\
\hline Total & & & & & & & & & & & & 348 & 180 \\
\hline
\end{tabular}

Based on the above data it is interesting to examine the phenomanon of woman representation in West Sumatera. Because the reality was the result of implementation of affirmative action policy through Law number 12 year 2003 about the determination of 30\% quota of woman in legislative institution which ideally can increase woman's representation in politics. In addition, in many cases, the condition of West Sumatra woman is not much different from the condition of woman in other regions in Indonesia (Idris, 2010a, 2010b; Subhan, 2004). This fact should be a common concern because West Sumatera culture, woman has a high and respected position in its matrilineal society. Even culturally Minangkabau society is an egalitarian society. It means everyone is equal. So in the past, not a few women became public figures who had a big influence on government policy, and even during the colonial government, such as Rohana Kudus, Siti Manggopoh, Rasuna Said, Rahmah El Yunusiah.

The low representation of woman in the Legislative raises the basic question, why it happens, while in West Sumatra the woman who are the icon of Bundo Kanduang have been given important places in decision making, both in indigenous peoples, county, and society.

If it is seen in the culture of Minangkabau people who embrace the matrilineal system, it is clear that woman has an important role. Minangkabau people, who are really bounded by the unity of descendants drawn by maternal or female line, is called tribe. The rights and obligations see in matrilineal principle; the nature and form of inheritance is according to one line only on the mother/female line/side and not on the father line/side as in Java, Batak and most other regions in Indonesia. This matrilineal system only shows for the determination of lineage, but woman who are often called bundo kanduang in Minangkabau has no power (Abdullah, 1970; Blackwood, 1995, 2001; Jamaris, 2002; Krier, 1995). The term matrilineal differs from matriarchaat. Matriarchaat implies that woman as a lineage and the holder of all power. But in Minangkabau culture the 
power belongs to unlce or ninik mamak. This can be seen in the unity of the tribe. Tribe and county are led by man. Bundo kanduang in Minangkabau culture has only inward power as in the case of marriage, inheritance, organizing and taking care of the Rumah Gadang (the big house). This is implied in the cultural view of "bundo kanduang limpapeh rumah nan gadang", which means that their power is only limited to the rumah gadang errands. Bundo kanduang in Minangkabau as the keeper and the holder of the wealth of her people, but woman are more in value as symbols or protecting symbols. Although bundo Kanduang holds the wealth of the heritage but she has no power to make decisions regarding it. The rights in maintenance, development and management of the inheritance are handed over to uncle or mamak. External power is all held by man, because the tribe in its interaction with other tribes, in or out of county is represented by mamak kaum or penghulu. This means that interactions associated with the public held by mamak / penghulu while bundo kanduang only entitled to govern the rumah Gadang or family.

In "Kaba Cinduo Mato", the story of Bundo Kanduang was so legendary in the matrilineal culture of the Minang society today, the belief in the importance of the existence of Bundo Kanduang as identification for the existence of an unchallenged power, a wise and caring Mother, which can not be separated from the life of the Minangkabau people both in the public and private sphere (Amaliatulwalidain, 2016; Faridah, 2012; Hidayat, Febriyanto, \& Nadzir, 2017; Ruaidah, 2017; Yazan, 2011). This Kaba shows the figure of Bundo Kanduang as a woman who was trusted by Minangkabau society as the first king of Pagaruyung kingdom and was recognized as a figure who laid the foundations of the Minangkabau government system based on Islam and matrilineal customs. Blackwood (2001) notes, Bundo Kanduang becomes a figure with his own language power in Minangkabau, reflected through the "Kaba" and other literary tales affecting the structure of his matrilineal society. The hereditary imagery to Minang woman is identical with Bundo Kanduang, who was a strong, nurture and wise character.

When a woman is responsible within the family area, it does not mean that she has to be merely a mother, a wife, or a daughter. Therefore, she is not only occupied with domestic tasks and shackled from her political activities. Conversely, when he is in the family area, he can participate in two types of work: educating and changing the political atmosphere. The Minangkabau society's principle alam takambang jadi guru (the worlds spread to be the lesson), no upper and lower classes, no distinction of the lower and upper classes as happened in the West. The reason, because these two things are separated working areas, but mutually intervention. In the book of western political science, there is a separation between the institutions of the family and the state institutions, but in Minangkabau society the family is an indispensable part of the county unit, the higher part of the government can act as the controller of the higher government.

Nevertheless, woman's political leadership in Minangkabau in families, communties and kinship. Her position is very crucial, because she is the determinant and controller of power, but until now the classification of science has not included the family, as the smallest social unit into the study of political science because it is rarely found books on the principles of political science that discusses the family in its own sub-section. Thus, contrary to the interpretation of power as a centralized power or the set of institutions within a state, the power in the Minangkabau concept is just like the Foucault concept that interprets power as a model of sophisticated strategy in a particular society, which is formed from separate micro-powers. About the concept of homogeneous power, Minangkabau culture derived from the whole of nature. the power of Minangkabau woman appears that power is not something that is public/formal/impersonal, but the personal is political, power can be determined personally, not infrequently be diplomatic, bargaining process actually happens in the 
most private space, namely the bedroom. Furthermore, these separate powers within the micro (family) scope may extend to the macro (public) sphere, one of them through the matrifocal network. Mothers always have a strong network among them, which will become more widespread with their interrelated habits. The conversation occurred with her husband in bed brought in to this networking conversation. No wonder that many cases for instance in the goverment units or even the lowest units that the husband position in the office will be largely determined by how woman's diplomacy in the network among them. A wife who never gets along is not only going to be ostracized, but the most important thing is she is not getting access to determine the position of the husband in the office. The empirical facts about this pattern of female behavior are by no means can not be seen formally, their power tends to slip between narrow gaps that will not be publicly visible (Handayani \& Novianto, 2004).

The people of West Sumatra still consider the family, kinship as a sacred that must be maintained in its integrity in achieving harmony in accordance with the philosophy of alam takambang jadi guru based on custom Adat basandi sarak, sarak basandi kitabullah which means Minangkabau woman in behaving or taking a decision which concerns careers outside the house must always adhere to the provisions of alur dan patut (groove and appropriateness); budi dan sangko (Mind and thought), as well as the values and norms taught by religion (Kosasih, 2013). It seems that the cultural burden borne by Minangkabau woman is still very heavy. Unlike Minangkabau, in Norway, it is possible that the cultural burden borne by woman is not as heavy as those borne by Minangkabau woman, as the issue of the missing marriage institution is undisputed; half of all children are now born to unmarried mothers. In the Pettersen area, $82 \%$ of couples get their first child out of wedlock. The numbers are equally high for Sweden and Denmark. Although many couples married after getting the first or second child, marriage institutions in some Scandinavian areas are now almost gone. But family policies in Scandinavian countries do not always give beneficiary to the woman, even though they are successful in government (politics), but for woman job seekers, they hardly find the employment in the private sector.

The reason, companies are reluctant to hire or promote woman because they need a lot of time off work to raise their children. Woman in minangkabau culture may have a career outside the house as long as it stays in the corridor of traditional philosophy adat basandi syarak, syarak basandi kitabullah. This works have nothing to do with the dependency on the man, but the confirmation that woman also have the same rights as man, as partners and as male companions. The study found that there is a gap between equality and representation, since there is no causal relationship between egalitarians and the votes that woman gain in elections, this is closely related to woman's political interests and awareness in taking action to run for the situational at the time. Based on field studies and in-depth interviews conducted with woman leaders, many of whom are highly educated; as professors, doctors, law scholars, social science scholars, and so on; but many of them are not interested in politics. As in the 2004 elections, few women were running for candidacy. There are at least four explanations for woman's decisions in politics: structural, cultural and religious, agency, and institutional (institutional). Minangkabau woman occupies low positions in parliamant: (1) because they can not afford resource; (2) they do not want (they are not interested); (3) no one asks them (no network); and (4) the rules (constitution) hinder them.

Therefore, in an effort to fulfill the quota of $30 \%$ of woman for legislative candidates, empirically and factually there are obstacles that cause woman's representation in the House of Representatives is very low that there is still the assumption that the world of politics is the world of man, the interest of woman is still low, the 
low level of woman's knowledge of politics, and the unfavorable support of political parties on woman. Thus, women, who will plunge into politics, must prepare themselves to be able to compete with man. For that reason woman should be active in the stewardship of political parties, and equip themselves by fulfilling their capacity, competence and qualifications as political citizens while remaining in the corridor of perfection of woman identity.

\section{Challenges and Constraints Faced by Woman in Political Involvement}

Feminists who embrace democratic pluralism believe that woman can not be disadvantaged simply because of their gender. As a human being, woman also need recognition of the existence of her womanhood. Feminist movements oppose stereotypical views that is potentially marginalized woman's role to the extent of their domestic function, not in the broader context of public life. Although the system and the direction of the government's political policies towards woman's issues are more gender-responsive, woman's position in the context of political power is still vulnerable to various forms of political manipulation and is often used as a tool of political legitimacy. The assumption is simple: woman are the basic unit in family and community life. Thus, control over the role of woman is an effective instrument in controlling all operations of state power. Various state regulations concerning woman's issues proved that the construction of patriarchal political culture throughout history is crucial to woman's lives. Since the 1960s, the wriggling feminist movements in various parts of the world (including Indonesia in the 1990s) continued to challenge the basic bias of gender-racially diverse policies, encouraged woman's roles, functions and positions more, and protested against the state conservative policies and the stigma of society that marginalizes woman's aspirations, rights, and interests. Feminists, who care about the importance of gender equality in building the nation's character, require progressive changes in woman's positions, as reflected in polemic of polygamy issues, domestic violence issues, woman's reproductive rights issues, or the issue of local regulations on prostitution. According to Arivia (2005), almost all state regulations related to woman are gender biased. Since in the structure of patriarchal society, woman's socio-cultural construction is often used as a tool of political legitimacy.

In this context, the fundamental challenges of the woman's movement in the future can at least be mapped into the following seven issues: First, neo-liberal globalization has spawned a world-class economic power centered in developed countries followed by economic restructuring in poor and developing countries. This situation has created an increasingly acute and complex poverty. The global economy has dragged woman as economic objects and commodities (being domestic workers, prostitute, migrant workers or factory workers and the low-paying informal sector). Second, the political autoritarism of the state. State control over excessive citizens-especially woman-has resulted in the presence of various state policies that bias human rights, bias gender, and reduce the nature of democracy. The emergence of various gender bias policies (such as the Anti Pornography and Anti-Porno-action bill and regional regulations based on a narrow interpretation of a particular religion), is a bit of evidence that the implementation of woman's civil and political rights has not yet fully gained the state of the country. Third, state policy is not pro-people. As we know, the state budget management (APBN/APBD), development priorities, and management of natural resources in the country are still fully based on meeting the needs of politicians, economic elites, investors, and global capital interests. This non-pro-people policy has reduced public access-particularly woman-in the education, health, work and basic public life sectors (food, energy, water, land and forests). Fourth, religious fundamentalism. Various religious movements that are allegedly attempting to fight against Western hegemony and the domination of capitalist 
forces based on radical, narrow, and one-sided attitudes and actions, have created a new excess in the presence of violence and oppression for woman. The emergence of mass organizations in the name of a particular religion and the realization of their attitudes and actions with radical understanding often make woman an object of violence. This organization often limits woman's movement and expression in politics, economy, social, and culture. Fifth, political liberalization occuring since the reformation era was not automatically followed by the readiness of educational institutions and political recruitment, especially political parties, to seriously and sustainably to open up opportunities for woman's participation in politics, especially to place woman in significant organizational positions and responsibilities, preparing and placing woman as legitimate candidates with equal opportunities with male candidates. Sixth, the woman's movement is thus challenged to be able to break down the lobbies of elitist male politicians and party politics that tend to be centralistic and patriarchal and also to change the political culture and mindset of the elite party to give greater space and opportunities to female political candidate to receive training and political education, including providing opportunities for woman to sit in various strategic positions and to be involved in policy-making processes. Seventh, even though the 30 percent quota is strategic, it is only one of the key elements in strengthening woman's political representation. After 2014 election, woman must expand the meaning of political representation. The involvement of woman in the political system for the purpose of representation is necessary, but it is certainly not sufficient. It means that the efforts of woman go politics not only as activities to enter the processes, mechanisms, institutions, and the political system (crafting democracy) but also how the political representation of woman is able to expand the base of constituents (broadening base).

Thus, the woman's movement must continue to advocate and educate critically at all levels of the woman's community. Various analytical perspectives to see the systemic oppression experienced by woman should be introduced, such as Marxian feminist analysis (to dissect oppression experienced by female workers); analysis of the Third World feminist movement (to dissect woman's oppression in the context of culture, religion, and forms of state violence); or ecofeminist analysis (to assess the oppression of woman from environmental and natural livelihood aspects). The various perspectives and strategies of woman's struggle are not only effectively used as a tool of intelligence and awareness, but more as an instrument in building a great coalition of woman's movements to realize equality, justice, tolerance and democracy.

From the existing challenges there are obstacles that become factors of low involvement of woman in politics in West Sumatra which shows that few woman participate in decision-making groups/public figures. Not only at the higher levels such as the state, but also at the lowest level, in the county. Woman's participation in public office is still minimal, while some still in doubt with the ability of woman to be leaders or take part in the political arena. This can be a reflection of why woman are always left behind and only few become leaders. Participation according to Sastropoetro (1988) is the mental and emotional involvement that encourages to contribute to the goals/ideals of the group and take responsibility for it.

To be involved in all aspects of political activity for woman is not easy. The current condition of West Sumatera woman is formed by obstacles that hamper political participation. The main constraints that are often used as a reason for the weakness of woman's political participation can be grouped into two, namely internal barriers and external barriers. Internal obstacles are woman's reluctance to engage in political activities. This reluctance is due to their socio-cultural that has not been able to actively voiced and convey their wishes and aspirations in politics. Activity is thought as not appropriate for woman, because of its nature which is far from the characteristics of woman. The world of politics is considered "harsh", "dirty", and full of tricks so it is 
considered unsuitable for the image of woman. The socio-cultural environment is less supportive of the development of woman's potency, such as the insight of parents, customs, the interpretation of inappropriate religious teachings, family income levels, and discriminative education systems. A traditional culture and the small access of woman on the mastery of socio-economic factors led to the formation of images in woman that they are behind man.

External obstacles according to Afan Gaffar include paternalistic bureaucracy, poorly balanced economic and political development patterns and poorly functioning political parties. The main obstacles to woman's political participation are in the socio-cultural environment which is less support for the development of woman's potency. Moreover, the inadequate policy of political development and the lack of functioning of political parties can be the source of the external barriers. Increasing political participation of woman can be pursued, such as providing political education that can create woman's ability and awareness of their rights and obligations in the political field.

Indeed, in this case, it cannot be inseparable from the presence of man who widely dominated the political arena, man are very dominant in formulating rules of political game; and it is man who often define standards for evaluation. Furthermore, political life is often regulated according to the norms and values of man, and in some cases, even according to the male lifestyle. For example, political models are based on the idea of "winners and losers", competition and confrontation, not on the basis of mutual respect, collaboration and consensus creation. This environment is often against woman. The existence of this male-dominated model causes woman to reject politics as a whole or to reject male-style politics. So when woman participate in politics, they tend to do so in small amounts.

In addition, community participation is also influenced by several factors such as education, literacy, writing, poverty, economics, social standing, self-belief, and superficial interpretation of religion (Sastropoetro, 1988). Interpretation of gender-biased religion makes it more difficult for woman to participate in development (Gratton, 2011; Nurhayati, 2012; Sulaiman, 2009). Notwithstanding this, in Minangkabau community which adapt the Adat Basandi Syarak, Syarak Basandi Kitabullah, there is also a gender bias in religious understanding, as found by Sasnifa (2017) that most of the Minangkabau religious figures and Minangkabau leaders have not been gender sensitive, because the insight, understanding, thinking of the figure is still colored by patriakhis socio-cultural principles, and a gender-biased religious understanding. Based on interviews with a number of community leaders in the locus county revealed that the justification of male leadership tends to be associated with Al-Quran Surah Annisa "verse 33". The interpretation of the verse that is believed by most people is that "Man are leaders for woman" it is impossible for woman to be leaders. Thus, woman are reluctant to get involved in the county management because they feel "man are better suited to take care of it".

Wibowo (2012) states that there are generally 3 (three) factors that cause low participation of woman in public area, including in government, that is:

1. Internal factors

Not infrequently, woman suffered from a weak mental attitude, easily give up, so she can not do maximally. Then, lack of willingness to improve the quality of self with a variety of positive activities to answer the demands of the times is low while this process is very important to form an insightful and nurturing leader.

\section{External factors}

Culture that affirms the division of the different roles of woman and man, woman in the domestic sphere, man in the public domain, has led to male domination in decision making in the public world including in 
government. So it is not uncommon decisions or public policy to ignore the existence of woman. Restrictions on the role of woman in the domestic world also tend to cause woman to limit and or restrict in improving their quality.

\section{Misunderstanding of religion}

It is still often found in the community of some who reject the existence of gender equality efforts, with the arguments of religion. Misunderstanding on pieces of verses of the Qur'an and hadith (in Islam), tend to judge woman lower than man. Whereas for Allah SWT, man and woman are equal. What makes them difference is only distinguished by their faith.

However, discussing the role of woman in politics should be accompanied by an optimistic attitude, although there are still many obstacles faced by woman to play a role in politics, but woman themselves must have a strong desire that their people must also play a role in the political field. Although there have been many studies and opinions that reveal the obstacles for woman to play a role in politics, it certainly does not necessarily change the proportion of woman who are active participating in political activities.

\section{Conclusions}

Achieving gender equality is one of the efforts to realize democratization, because with gender equality will open opportunities and chances for all people from all community to participate in the democratization process itself. But the reality is that there are still very few women in the research loci in West Sumatra who participate in the democratization process in regional autonomy and return to the county. Constraints arise not only from the political side, but also from the patriarchal values that are still thick. A very strong view of the value system, norms, myths, and stereotypes about woman is an ideological barrier. This ideology is also reflected in the interpretation of religious teachings that are used as a justification for rejecting gender equality. Understanding this ideology not only by man but also by woman, they tend to still accept the concepts that actually marginalize woman in development. Therefore, the need for participation from all parties to participate in dismantling patriarchal values that are actually more harmful to woman, and in turn will harm society as a whole, in all lines of life. Early efforts to realize gender equality can be initiated from family, school and community, as a step towards realizing democratization itself.

\section{References}

Abdullah, T. (1970). Some notes on the Kaba Tjindua Mato: An example of Minangkabau traditional literature. Indonesia, 9 , $1-22$.

Amaliatulwalidain, A. (2016). Dinamika representasi peran politik bundo kanduang dalam sistem pemerintahan nagari moderen dari representasi substantif menuju representasi formal deskriftif. Jurnal Pemerintahan Dan Politik (The representation dynamicity on the exintance of Bundo Kanduang in Modern Nagari Government system from substantive toward formal descriptive representation). Journal of Government and Politic, 1(1), 1-7.

Arivia, G. (2005). SBY and Women's Navels. Kompas.

Blackwood, E. (1995). Senior women, model mothers, and dutiful wives: Managing gender contradictions in a Minangkabau village. In A. Ong, \& M. G. Peletz (Eds.), Bewitching women, Pious Men: Gender and body politics in Southeast Asia (pp. 124-58). Berkeley: University of California Press.

Blackwood, E. (2001). Representing women: The politics of Minangkabau Adat writings. The Journal of Asian Studies, 60(1), 125-149.

Bloomberg, L. D., \& Volpe, M. (2008). Analyzing data and reporting findings. In L. D. Bloomberg, \& M. Volpe (Eds.), Completing your qualitative dissertation: A roadmap from beginning to end (pp. 94-126). Thousand Oaks: Sage.

Budiardjo, M. (2003). Dasar-dasar ilmu politik (The fundamental of politics). Gramedia Pustaka Utama. 
Carli, L. L., \& Eagly, A. H. (2001). Gender, hierarchy, and leadership: An introduction. Journal of Social Issues, 57(4), 629-636.

Cohen, J. M., \& Uphoff, N. T. (1977). Rural development participation: Concepts and measures for project design, implementation and evaluation. New York: Cornell University.

Dahlerup, D. (2005). Increasing women's political representation: New trends in gender quotas. In J. Ballington, \& A. Karam (Eds.), Women in parliament: Beyond numbers. Stockholm: IDEA.

Davis, R. H. (1997). Women and power in parliamentary democracies: Cabinet appointments in Western Europe, $1968-1992$ (Vol. 2). U of Nebraska Press.

De Dreu, C. K., \& West, M. A. (2001). Minority dissent and team innovation: The importance of participation in decision making. Journal of Applied Psychology, 86(6), 1191.

Dhesi, A. S. (2000). Social capital and community development. Community Development Journal, 35(3), 199-214.

Faridah, F. (2012). Keterlibatan perempuan dalam bermasyarakat: Studi pada masyarakat pantai Kabupaten Padang Pariaman (The women participation in social life: A study on the Beach Society of Padang Pariaman). Humanus, 11(1), 1-11.

Gratton, K. (2011). Pendapat perempuan tentang perempuan dalam dunia politik pada era reformasi dan masa depan (The women opinion on politic in the progress and after Reformation Era) (pp. 23-27).

Hadi, A. P. (2010). Konsep Pemberdayaan, Partisipasi dan Kelembagaan Dalam Pembangunan (The empowerment concept, participation and institution in the developmet). Jurnal Yayasan Agribisnis/Pusat Pengembangan Masyarakat Agrikarya (PPMA).

Hamad, I. (2008). Memahami Komunikasi Pemasaran Politik (Understanding the communication polical marketing). MediaTor (Jurnal Komunikasi), 9(1), 147-162.

Handayani, C. S., \& Novianto, A. (2004). Kuasa Wanita Jawa (The power of Javanese women). PT LKiS Pelangi Aksara.

Hidayat, Y., Febriyanto, I. I., \& Nadzir, M. H. (2017). Transformasi dan Dualisme Kelembagaan dalam Pemerintah Adat Minang: Studi terhadap Nagari Pariangan, Sumatera Barat (The transformation and dualism at Minangkabau Traditional Officials: A study at "Nagari Pariangan" West Sumatera). Politik Indonesia: Indonesian Political Science Review, 2(2), 227-245.

Idris, N. (2010a). Fenomena, Feminisme dan Political Self Selection Bagi Perempuan (The phenomenon, feminismand political self collection for women). WACANA, Jurnal Sosial Dan Humaniora, 13(1), 116-131.

Idris, N. (2010b). Perempuan Minangkabau dalam Politik (The Minangkabau women in politic). Jurnal Humaniora, 22(2), 164-175.

Inglehart, R., \& Norris, P. (2003). Rising tide: Gender equality and cultural change around the world. Cambridge University Press.

Irvin, R. A., \& Stansbury, J. (2004). Citizen participation in decision making: Is it worth the effort? Public Administration Review, 64(1), 55-65.

Ismanto, I. (2004). Pemilihan presiden secara langsung 2004: dokumentasi, analisis, dan kritik (The Direct Precidential Election 2004: Documentation, analysis and critics). Galangpress Group.

Jamaris, E. (2002). Pengantar sastra rakyat Minangkabau (The introduction native Minangkabau literature). Yayasan Obor Indonesia.

Kosasih, A. (2013). Upaya penerapan nilai-nilai adat dan syarak dalam penyelenggaraan pemerintahan nagari (Efforts on custom values application and Syara' in the runing of Nagari Government). Humanus, 12(2), 107-119.

Krier, J. (1995). Narrating herself: Power and gender in a Minangkabau woman's tale of conflict. Bewitching Women, Pious Men: Gender and Body Politics in Southeast Asia (pp. 51-75).

Lincoln, Y. S., \& Denzin, N. K. (2003). Turning points in qualitative research: Tying knots in a handkerchief. Rowman Altamira.

Lovenduski, J., \& Karam, A. (2002). Women in parliament: Making a difference. International IDEA, Women in Parliament, Stockholm.

McDonald, P. (2000). Gender equity in theories of fertility transition. Population and Development Review, 26(3), 427-439.

Mikkelsen, B. (2011). Metode penelitian partisipatoris dan upaya pemberdayaan: Panduan bagi praktisi lapangan (The participatory research methods and efforts of epowerment: The guidelines for Fielt participants). Yayasan Pustaka Obor Indonesia.

Nurhayati, E. (2012). Psikologi Perempuan dalam Berbagai Perspektif (The women psychology in different perspectives). Jogjakarta.

Paxton, P. (1997). Women in national legislatures: A cross-national analysis. Social Science Research, 26(4), $442-464$.

Paxton, P., Hughes, M. M., \& Painter, M. A. (2010). Growth in women's political representation: A longitudinal exploration of democracy, electoral system and gender quotas. European Journal of Political Research, 49(1), 25-52. 
Paxton, P., Kunovich, S., \& Hughes, M. M. (2007). Gender in politics. Annu. Rev. Sociol., 33, 263-284.

Purnamasari, I. (2008). Studi partisipasi masyarakat dalam perencanaan pembangunan di Kecamatan Cibadak Kabupaten Sukabumi (The study on the society participations in the Developmental Plans in Cibadak, Sukabumi). Program Pascasarjana Universitas Diponegoro.

Radjab, M. (1969). Sistem Kekerabatan di Minangkabau (The Kinship system of Minangkabau). Center for Minangkabau Studies.

Ragin, C., \& Amoroso, L. M. (2011). Using qualitative methods to study commonalities. Constructing Social Research, The Unity and Diversity of Method, 2, 111-134.

Rauf, H. I. (1997). Wanita dan Politik Pandangan Islam (Women and politic in Islam). Bandung: Remaja Rosda Karya.

Renn, O., Webler, T., Rakel, H., Dienel, P., \& Johnson, B. (1993). Public participation in decision making: A three-step procedure. Policy Sciences, 26(3), 189-214.

Ruaidah, R. (2017). Ideologi Feminisme dalam Kaba Cindua Mato (Feminism ideology in Kaba Cindua Mato). Kafaah: Journal of Gender Studies, 7(1), 15-25.

Rule, W., \& Zimmerman, J. F. (1994). Electoral systems in comparative perspective: Their impact on women and minorities. Greenwood Publishing Group.

Sasnifa, P. (2017). Rekonstruksi Kesetaraan Gender dalam Konteks Pranata Hukum, Budaya dan Agama (The reconstruction of dender equality in the law institutional context, curture and religion). Harakat an-Nisa'Jurnal Studi Gender Dan Anak (Harakat an-Nisa jurnal Gender and Child Studies), 2(1), 23-29.

Sastropoetro, R. A. S. (1988). Partisipasi Komunikasi, Persuasi dan Dispilin dalam Pengembangan Pembangunan (The communication participation, persuasion and diciplines in the development construction). Penerbit Alumni. Bandung.

Shafiyyah, A. (2003). Kiprah politik muslimah: konsep dan implementasinya (The existance of Islamic women: The concepts and its implications). Gema Insani.

Simamora, J. (2011). Eksistensi Pemilukada Dalam Rangka Mewujudkan Pemerintahan Daerah yang Demokratis (The existance of district general election in managing the democracy). Mimbar Hukum (The Law Forum), 23(1), 221-236.

Stockemer, D. (2009). Women's parliamentary representation: Are women more highly represented in (consolidated) democracies than in non-democracies? Contemporary Politics, 15(4), 429-443.

Subhan, Z. (2004). Perempuan dan politik dalam Islam (Women and Islamic political view). PT LKiS Pelangi Aksara.

Sulaiman, A. (2009). Kebijakan Partai Politik Terhadap Caleg Perempuan pada Pemilu 2009 di Bangka Belitung (The political parties regulation toward female political candidate on the 2009th Distric General Election in Bangka Belitung). SOCIETY, $1(1), 1-17$.

Taylor, M. F., Suckling, K. F., \& Rachlinski, J. J. (2005). The effectiveness of the Endangered Species Act: A quantitative analysis. BioScience, 55(4), 360-367.

Taylor, S. J., Bogdan, R., \& DeVault, M. (2015). Introduction to qualitative research methods: A guidebook and resource. John Wiley \& Sons.

Thames, F. C., \& Williams, M. S. (2013). Contagious representation: Women's political representation in democracies around the world. NYU Press.

Van Deth, J. W. (2001). Studying political participation: Towards a theory of everything. Proceedings from The Workshops of the European Consortium for Political Research, Grenoble (pp. 6-11).

Wibowo, D. E. (2012). Peran ganda perempuan dan kesetaraan gender (The two sided roles of women and the gender equality). Muwazah, 3(1), 2-7.

Winarno, B. (2007). Sistem politik Indonesia era reformasi (Indonesian political system in the Era of Reformation). Gramedia Pustaka Utama.

Witt, L. A., Andrews, M. C., \& Kacmar, K. M. (2000). The role of participation in decision-making in the organizational politics-job satisfaction relationship. Human Relations, 53(3), 341-358.

Wulan, T. R. (2008). Pemetaan gerakan perempuan di indonesia dan implikasinya terhadap penguatan public sphere di pedesaan (The mapping the Indonesia women movement and its' implication in promoting the villages public sphere). Yin Yang, 3(1), 120-139.

Yazan, S. (2011). Piramida deiksis perempuan Minangkabau (The Minangkabau Women Diexies Pyramid). Kafaah: Journal of Gender Studies, 1(2), 137-150. 